\title{
Erratum
}

\section{Superoxide radicals play important roles in the pathogenesis of spinal cord injury}

\author{
Y Taoka, M Naruo, E Koyanagi, M Urakado and M Inoue \\ Paraplegia 1995; 33: 450-453
}

In the publication of the above paper, the references $26-28$ were incorrect. A revised version of the references is given below.

\section{References}

1 Silver JR. Vascular reflexes in spinal shock. Paraplegia 1971; 8: 231-242.

2 Troll GF, Dohrmann GJ. Anaesthesia of the spinal cord-injured patient: cardiovascular problems and their management. Paraplegia 1975; 13: 162-171.

3 Gonzalez F et al. Autoregulation of cerebral blood flow in patients with orthostatic hypotension after spinal cord injury. Paraplegia 1991; 29: 1-7.

4 Ozcan O, Ulus H, Yurtkuran M, Karakaya M. Release of vasopressin, cortisol and $\beta$-endorphin in tetraplegic subjects in response to head-up tilt. Paraplegia 1991; 29: 120-124.

5 Anderson DK, Means ED. Lipidperoxidation in spinal cord. Neurochem. Pathology 1983; 1: 249-264.

6 Braughler JM, Duncan LA, Chase RL. Interaction of lipid peroxidation and calcium in the pathogenesis of neural injury. Cent Nerv Syst Trauma 1985; 2: 269-283.

7 Taoka Y, Ikata T, Fukuzawa K. Influence of dietary vitamin E deficiency on compression injury of rat spinal cord. J Nutr Sci Vitaminol 1990; 36: 217-226.

8 Demopoulos HB, Flamm ES, Pietronigro DD, Seligman ML. The free radical pathology and the microcirculation in the major central nervous system disorders. Acta Physiol Scand Suppl 1980; 492: 91-119.

9 Anderson DK et al. Spinal cord injury and protection. Ann Emerg Med 1985; 14: 816-821.

10 Inoue M, Ebashi I, Watanabe N, Morino Y. Synthesis of a superoxide dismutase derivative that circulates bound to albumin and accumulates in tissue whose $\mathrm{pH}$ is detected. Biochemistry 1989; 28: 6619-6624.

11 Alexander S, Kerr FWL. Blood pressure responses in acute compression of the spinal cord. J. Neurosurgery 1964; 21: 485-491.

12 Wallace MC, Tator CH. Successful improvement of blood pressure, cardiac output, and spinal cord blood flow after experimental spinal cord injury. Neurosurgery 1987; 20 $710-715$

13 Young W, DeCrescito V, Tomasula J, Ho V. The role of the sympathetic nervous system in pressor responses induced by spinal cord injury. J. Neurosurg. 1980; 52: 473-481.
14 McIntosh TK, Faden AAI. Opiate antagonist in traumatic shock. Ann Emerg Med 1986; 15: 1462-1465.

15 Holaday JW, Faden AI. Naloxone acts on central opiate receptors to reverse hypotension, hypothermia and hypoventilation in spinal shock. Brain Res 1980; 189: 295-299.

16 Faden AI et al. Neuropeptides in spinal cord injury: comparative experimental models. Peptides 1983; 4: 631-634.

17 Young WY et al. Effect of naloxone on post traumatic ischemia in experimental spinal contusion. J Neurosurg 1981; 55: 209-219.

18 Pietronigoro DD, Hovesepian M, Demopoulos HB, Flamm ES. Loss of ascorbic acid from injured feline spinal cord. J Neurochem 1983; 41: 1072-1076.

19 Saunders RD et al. Effects of methylprednisolone and the combination of $\alpha$-tocopherol and selenium on arachidonic acid metabolism and lipid peroxidation on traumatized spinal cord tissue. J Neurochem 1987; 49: 24-31.

20 Koreh K, Seligman ML, Flamm ES. Lipid antioxidant properties of naloxone in vitro. Biochem Biophys Res Comm 1981; 102: $1317-1322$

$21 \mathrm{Lim} \mathrm{KH}$ et al. Prevention of reperfusion injury of the ischemic spinal cord: use of recombinant superoxide dismutase. Ann Thorac Surg 1986; 42: 282-286.

22 Ganong WF. Control of posture and movement. In: Ganong WF (ed). Review of Medical Physiology. 11th edn. Maruzen Asia: Singapore, 1983, p 160.

23 Guttmann L, Munro AF, Robinson R, Walsh JJ. Effect of tilting on the cardiovascular responses and plasma catecholamine levels in spinal man. Paraplegia 1963; 1: 4-18.

24 Furchgott RF, Zawadzky JV. The obligatory role of endothelial cells in the relaxation of arterial smooth muscle by acetylcholine. Nature 1980; 288: 373-376.

25 Gryglewski RJ, Palmer MJ, Moncada S. Superoxide anion is involved in the breakdown of endothelium-derived vascular relaxing factor. Nature 1986; 320: 454-456.

26 Nakazono $\mathrm{K}$ et al. Does superoxide underlie the pathogenesis of hypertension? Proc Natl Acad Sci USA 1991; 88: 10045-10048.

27 Breckenridge A. Hypertension and hyperuricemia. Lancet 1966; 1: 15-18.

28 Cannon $\mathrm{P}$ et al. Hyperuricemia in primary and renal hypertension. N Engl J Med 1966; 275: 457-464. 